Girard, K.F. \& Murray, E.G.D. (1951) Listeria monocytogenes as a cause of disease in man and animals and its relation to infectious mononucleosis. American Journal of Medical Science, 221, 343.

GRAY, M.L. (1962) Listeria monocytogenes in the diagnostic laboratory. Annals of the New York Academy of Science, 98, 686.

Harding, J.W. \& Brunton, G.B. (1962) Listeria monocytogenes meningitis in neonates. Lancet, ii, 484.

LIBRACH, I.M. \& SETH, R.K. (1961) Human Listerial Meningitis. Journal of Clinical Pathology, 14, 193.

MacNaughton, M.C. (1962) Listeria monocytogenes in abortion. Lancet, ii, 484.

Murray, E.G.D., Webb, R.A. \& SWanN, M.B.R. (1926)
Disease of rabbits by undescribed bacillus. Journal of Pathology and Bacteriology, 29, 407.

OWen, C.R., Meis, A., Jackson, J.W. \& Stoenner, H.G. (1960) A case of primary cutaneous listeriosis. New England Journal of Medicine, 262, 1026.

RAY, C.G. \& WEDGWOOD, R.J. (1964) 6 case reports and review of the literature. Paediatrics, 34, 378.

ToafF, R., KrochiK, N. \& Rabinovitz, M. (1962) Genital listeriosis in the male. Lancet, ii, 482.

Welshimer, H.J. \& WingleWISH, N.G. (1959) Listeriosissummary of 7 cases of listeria meningitis. Journal of the American Medical Association, 171, 1319.

WhitTy, C.W.M. \& Macaulay, J.D. (1965) Listeria monocytogenes meningoencephalitis in an adult. British Medical Journal, 1, 634.

\title{
Pneumoperitoneum associated with Escherichia coli peritonitis: a report of two cases
}

\author{
J-N. PoIlly* \\ M.B., F.R.C.S. \\ Registrar, Department of Surgery, Southern General Hospital, Glasgow, S.W.1
}

THE FINDING of a pneumoperitoneum on X-ray of the acute abdomen prior to operation usually signifies the presence of a perforation of the gastrointestinal tract. Very occasionally however no perforation is present, and this may lead to difficulty in diagnosis. The following two cases are published as an illustration of this latter instance.

\section{Case reports}

Case 1

Mrs. M.G., a 48-year-old housewife required emergency admission to hospital with a 3-day history of colicky lower abdominal pain accompanied by abdominal distention and vomiting. For 4 days prior to the onset of her pain, she had suffered from nausea and anorexia and had been feeling generally weak and unwell.

Her past medical history was negative.

On examination, her temperature was $100 \cdot 8^{\circ} \mathrm{F}$, pulse rate 108, and blood pressure $105 / 70 \mathrm{mmHg}$. Her abdomen was distended, and there was tenderness in the lower part of the abdomen. The bowel sounds were slightly increased. Rectal examination was negative.

An X-ray of the abdomen in the erect position showed numerous fluid-levels in the distended small bowel; gas was also present under both domes of the diaphragm, particularly on the left (Fig. 1). The haemoglobin was $12 \cdot 6 \mathrm{~g} / 100 \mathrm{ml}$, WBC 11,400 cells $/ \mathrm{mm}^{3}$. A blood-film showed evidence of neutrophilia.

*Present address: Bradford Royal Infirmary, Bradford 9.

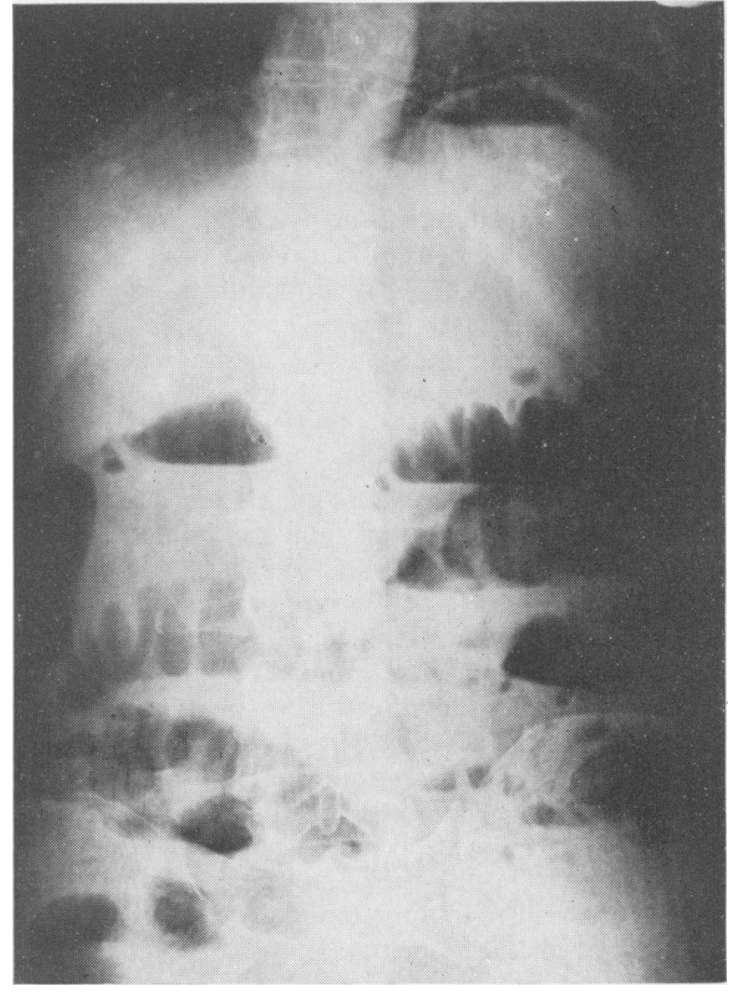

FIG. 1. X-ray of abdomen in erect position showing fluid levels in distended small bowel and gas under the diaphragm. 
Operation. It was decided to carry out a laparotomy, and the patient was found to have an abscess containing about $50 \mathrm{ml}$ of thick pus in relation to the right Fallopian tube which was inflamed; a loop of ileum had become adherent to the roof of the abscess, causing an acute intestinal obstruction; the remainder of the peritoneal cavity contained seropurulent fluid. The large and small bowel, stomach and duodenum were carefully inspected for evidence of a perforation, but none could be found. The obstructed loop of bowel was freed and the pus in the abscess cavity and in the peritoneum drained. The abdomen was closed, drainage being established by a corrugated rubber drain.

Antibiotic therapy was commenced. At first a course of cephaloridine was given later to be changed to penicillin and streptomycin.

Post-operatively, a wound infection and later, a right lower lobe pneumonia complicated the patient's recovery. Further progress was satisfactory and the patient was discharged home $3 \frac{1}{2}$ weeks after her admission to hospital. She has now been followed up as an out patient for a year during which time she has been free of symptoms, has been feeling very well, and has been steadily gaining weight.

The bacteriological swabs taken at operation of the seropurulent fluid in the general peritoneal cavity and of the thicker pus in the pelvic abscess both produced a heavy growth of Escherichia coli sensitive to ampicillin, streptomycin, tetracycline, and cephaloridine. No other organisms were found and in particular, no anaerobic bacteria were isolated. A high vaginal swab taken 16 days after operation and after the commencement of antibiotic therapy grew eight colonies of Esch. coli, but the sensitivity pattern was different from that of the organisms cultured at the operation.

A barium meal and later gastroscopy carried out after the patient had been discharged from hospital showed no evidence of peptic ulceration; a barium follow-through examination was negative, and a barium enema showed evidence of a moderate short segment of diverticular disease in the mid-sigmoid colon. Examination of the faeces for occult blood was negative.

\section{Case 2}

Mrs. A.McN., a 48-year-old housewife, was admitted to hospital in a moribund condition and was unable to give an adequate history. Her husband stated that she had had pain in the lumbar region for 8 weeks. This pain had become worse 4 weeks after its onset, and even more severe 2 weeks later. On the eve of admission she started vomiting and shortly before admission she had collapsed with sudden severe anterior abdominal pain which was generalized. The patient's appetite had been poor, and in the few weeks before admission to hospital, she had lost over 4 stones in weight.

Her past medical history was negative apart from chronic leg ulcers which had responded to treatment.

On examination, the patient, who was still very obese, was shocked and very dyspnoeic. Her pulse and blood pressure were not recordable. Her apex rate was 120 . Her tongue was furred and dry. Her abdomen was distended and there was marked rebound tenderness in the lower abdomen but no rigidity was present. Bowel sounds could not be heard. Rectal examination was negative.

An X-ray of the abdomen showed a large pneumoperitoneum.

After resuscitation with intravenous fluids and hydrocortisone the patient was taken to theatre.

Operation. When the peritoneum was opened, a large amount of foul-smelling gas escaped and 3 litres of thick pus were aspirated. There was obvious gross peritonitis with fibrin coating the gut. A careful search of the abdominal organs failed to reveal any cause for this and in particular there was no perforation of the gastro-intestinal tract. The peritoneum was drained and the wound closed over a large corrugated rubber drain.

Post-operatively, the patient deteriorated and she died a few hours later.

At necropsy, the cause of the peritonitis was found to be a right perinephric abscess which had ruptured anteriorly into the peritoneal cavity. A bacteriological swab taken at operation grew Esch. coli. There were no anaerobic organisms present.

\section{Discussion}

Falkenburg in 1913 described two cases with tension pneumoperitoneum developing post-operatively in the absence of a perforated viscus. Additional cases were described by Fründ in 1914 and Stegemann in 1923, but in none of these four cases were bacteriological studies carried out. Rhodes in 1936 reported a case of pneumoperitoneum associated with generalized peritonitis caused by a Clostridial infection. A similar case was reported by Adams (1946) and here too, Clostridia were found on bacteriological study. Doberneck \& Reiser (1964) described a case of pneumoperitoneum with generalized peritonitis, bacteriological culture of the peritoneal fluid grew Esch. coli and Clostridia. The first report of pneumoperitoneum associated with salpingitis was made by Rawls in 1966 when he reported two cases; the salpingitis had given rise to pelvic peritonitis and in the first case, bacteriological culture of the peritoneal fluid grew Streptococcus viridans, coagulase-negative Staphylococcus epidermidis, and Aerobacter cloacae, the formation of the gas being presumably attributable to the latter; 
unfortunately in his second case no satisfactory bacteriological studies were carried out.

In the cases reported in the present paper, pneumoperitoneum appears to have been caused purely by the well known ability of many strains of Esch. coli to ferment carbohydrates with the production of gas (Fairbrother, 1953). A search of the literature has failed to reveal any other similar case reports.

When pneumoperitoneum is found preoperatively in an acute abdomen, laparotomy is indicated provided the patient's general condition allows it. A careful search should be made for a perforation of the gastro-intestinal tract. If none can be found but evidence of peritonitis is present, a swab for an immediate gram stain and bacteriological culture both anaerobic and aerobic should be taken. It is advisable to start the patient on adequate antibiotics in case the peritonitis is caused by a Clostridial infection. Treatment with gas gangrene antisera is also advisable until the result of the bacteriological culture becomes available.
Acknowledgments

I wish to thank Mr J. H. Levack and Mr H. I. Tankel, Consultant Surgeons, Southern General Hospital, Glasgow, for permission to publish these two cases who were under their care, and to Mr A. Litton, Consultant Surgeon, Southern General Hospital, Glasgow, for his help in writing this paper.

\section{References}

AdAms, R. (1946) Gas bacillus infection following biliary surgery. Surgical Clinics of North America, 24, 551.

DoberneCK, R.C. \& Reiser, M.P. (1964). Pneumoperitoneum due to generalized peritonitis caused by gas forming organisms. Minnesota Medicine, 47, 1344.

FAIRBROTHER, R.W. (1953) A Textbook of Bacteriology, 7th edn, p. 227. Heinemann, London.

FALKENBURG, C. (1913) Ein Fall von Garansammlung in der freien Bauchhöle. Deutsche Zeitschrift für Chirurgie, $124,130$.

FrüND, H. (1914) Gasbildung in der freien Bauchhöle. Deutsche Zeitschrift für Chirurgie, 130, 585.

RAWLS, G.H. (1966) Salpingitis as a cause of pneumoperitoneum. Journal of Indiana State Medical Association, 59, 798.

Rhodes, R.L. (1936) Abdominal gas bacillus catastrophe. Annals of Surgery, 103, 804.

Stegemann, H. (1923) Gas peritonitis. Archiv für Klinische Chururgie, 123, 523.

\section{Cerebral malaria in the Port of Bristol}

\author{
M. A. KHAN \\ M.B., M.R.C.P., D.T.M.\&H. \\ Registrar in General Medicine, \\ Southmead/Ham Green Hospitals, Bristol \\ J. F. SKONE \\ M.D., D.P.H., D.I.H. \\ Deputy Port Medical Officer, Bristol
}

\author{
E. R. Williams \\ M.A., M.B., M.R.C.P. \\ Senior Registrar and Tutor in Medicine, \\ United Bristol Hospitals
}

THE DRAMATIC onset and poor prognosis of cerebral malaria is well known. With rapid international travel from malarial areas this condition may be expected to occur from time to time anywhere in this country (Hutton, 1969). Recent correspondence has stressed this and similar hazards to public health (Macgraith, 1969; Bruce-Chwatt, 1969).

Between July 1968 and March 1969, three cases, two fatal, of cerebral malaria have occurred in seamen passing through the Port of Bristol and it is felt that the difficulties encountered in the prompt diagnosis of these cases should be recorded.

\section{Case reports}

Case 1

On 10 July 1968, a 50-year-old Spanish sailor who had just returned from the West Coast of Africa via the Canary Islands was seen on arrival in Bristol with a temperature of $38.8^{\circ} \mathrm{C}$, headache, and left sided chest signs. Achromycin was prescribed and 2 days later he was better, with normal temperature. Four days later he was not so well but proceeded on his voyage to Liverpool where he was found unconscious in his cabin and on admission to hospital was deeply unconscious. A lumbar puncture was entirely normal, but blood film revealed infection with Plasmodium falciparum with a parasitaemia of $9 \%$. He was treated with parenteral chloroquine and although he remained comatose for five days after admission, eventually made a full recovery with no residual neurological sequelae (Smith \& Harper, 1968).

\section{Case 2}

A 36-year-old Asian cook became unwell shortly before arriving at Bristol on 6 February 1969. His ship had been loading in various parts of West Africa including Lagos from 24 December to 27 